\title{
OK18 - en forklaring af forløbet og en ny forståelse af magtbalancen
}

Nana Wesley Hansen \& Mikkel Mailand

OK18 var den hidtidig mest dramatiske overenskomstforhandling på det offentlige område i Danmark. I artiklen argumenter vi for det første, at OK18 processen og forligene var et resultat af musketereden og fagbevægelsens succesfulde mobilisering af kernetropper og befolkning, samt af en parlamentarisk situation med en borgerlig regering og et forestående folketingsvalg, hvor et lovindgreb ikke så nemt ud. For det andet argumenterer vi, at et af hovedproblemerne for det offentlige aftalesystem i dansk forskning er blevet begrebsliggjort i form af de statslige arbejdsgiveres såkaldte dobbeltrolle, som skulle give et særligt ulige magtforhold mellem den statslige arbejdsgiver og lønmodtagerne, men at denne forståelse bør nuanceres. Den nyere historie i det offentlige aftalesystem i Danmark - særligt OK13 - bekræfter umiddelbart, at dobbeltrollen kan være et stærkt magtmiddel for arbejdsgiverne. Men OK18 vidner om, at denne forståelse af magtbalancen i det offentlige aftalesystem ikke kan forklare begivenhederne.

Nøgleord: Offentlig aftalesystem, magtressourcer, politisk magt, forhandlingsstrategi, OK18

\section{Indledning}

Overenskomstforhandlingerne 2018 i den offentlige sektor var det mest komplicerede forløb i det offentlige aftalesystems historie. For første gang var samtlige lønmodtagere og arbejdsgivere på det offentlige område i Forligsinstitutionen sammen, og for første gang var der overhængende fare for en storkonflikt alene på det offentlige arbejdsmarked. OK13 og OK15 havde stor betydning for den mobilisering, som lønmodtagerne foretog op til og under OK18. Særligt disse to overenskomstrunder har aktualiseret debatten om et af de centrale kendetegn ved den offentlige aftalemodel. Navnlig magtforholdet i modellen og herunder især de statslige arbejdsgiveres såkaldte dobbeltrolle har været problematiseret (Hansen, 2016; Hansen og
Seip, 2018; Høgedahl, 2019; Høgedahl og Ibsen, 2015; Mailand, 2014; Sorgenfrey, 2015; Vinther, 2015).

Denne artikel har to formål. For det første vil vi forsøge at forklare, hvorfor OK18 processen og forligene endte, som de gjorde. For det andet vil vi herigennem bidrage til forståelsen af aktørernes mobilisering af forskellige magtressourcer gennem analyse af aktørernes strategier under forhandlingerne og nuancere tesen om det ulige magtforhold i den offentlige aftalemodel.

I næste afsnit gennemgår vi teoretiske antagelser om de magtressourcer, som aktørerne har til rådighed, og hvordan disse ressourcer spiller sammen med grundlæggende karakteristika ved den danske aftalemodel i det offentlige. Dernæst følger et kort 
metodeafsnit. Herefter indleder vi analysen med en kort beskrivelse af baggrunden og processen under OK18. Selve analysen er organiseret i fire afsnit ud fra fire afgørende perspektiver, der tilnærmelsesvis kan forstås som aktør-perspektiver. Først analyseres lønmodtagernes forhandlingsstrategi, dernæst arbejdsgivernes forhandlingsstrategi. Det tredje analyseafsnit behandler udmeldinger, politikere og samspillet mellem aftalesystemets aktører og det politiske system. Endelig analyserer vi i det fjerde afsnit Forligsinstitutionens rolle. Dette følges op af en diskussion om magtbalancer i det offentlige aftalesystem. Artiklen afsluttes med en samlet konklusion.

\section{Magtressourcer og magtbalance $i$ industrial relations litteraturen}

I den internationale og danske forskning $\mathrm{i}$ arbejdsmarkedsrelationer er det en grundlæggende forståelse, at arbejdsgiverne både i det private og i det offentlige i kraft af retten til at hyre og fyre samt lede og fordele arbejdet har en særligt magtfuld position i forhold til lønmodtagerne. Ved etablering af kollektive aftaleforhandlinger udlignes magtbalancen delvist. Men der er fortsat tale om asymmetri (Flanders, 1970). Mens denne asymmetri i den private aftalemodel bygger på arbejdsgivernes råderet over produktionsmidlerne, så har en forståelse i dansk forskning været, at den i det offentlige i Danmark bygger særligt på de statslige arbejdsgiveres dobbeltrolle, hvor de på den ene side er den forhandlende part - ofte med Finansministeren som hovedforhandler - og på den anden side er en væsentlig del af det lovgivende system (Petersen, 1987; Pedersen, 1993; Due og Madsen, 1996; 2015; Jacobsen og Pedersen, 2010) ${ }^{1}$.

Magtasymmetrien mellem lønmodtager og arbejdsgiver er et grundelement i forståelsen af ansættelsesrelationen (Kelly, 2008, s. 14). Magt forstås grundlæggende i arbejdsmarkedsforskningen som et relationelt fænomen, hvor magt til den ene part ikke nødvendigvis betyder mindre magt til den anden part. Tværtimod kan magtfulde fagforeninger være grobund for mere samfundsmæssig indflydelse til arbejdsgiverne i en aftalemodel (Wright, 2000, 962; Ibsen, 2015).

I overensstemmelse med den internationale litteratur om magt $i$ ansættelsesrelationen betragter vi i denne analyse magt som besiddelse af potentielle ressourcer (Kelly, 2008; Lévesque and Murray, 2010; Ibsen, 2015; Hansen og Seip, 2018; Schmidt et al., 2018). Vi forsøger derudover at formulere en mere dynamisk forståelse af de 'politiske muligheder' for at anvende de magtressourcer, som arbejdsmarkedets parter i den offentlige sektor i Danmark har til rådighed i givne politiske kontekster (McAdam, 2004; Lévesque and Murray, 2010). Fremfor at fokusere på aktørernes kompetencer i forhold til at anvende deres magtressourcer, fokuserer vi i denne artikel på den politiske arena og hvilke muligheder denne giver aktørerne for at anvende deres magtressourcer i forhandlingsarenaen

I litteraturen om magtressourcer skelnes der klassisk mellem magt lokaliseret i fagforeningernes organisatoriske ressourcer (såsom fx organiseringsgrad, TR dækning, strejkekasse styrke mv., hvor de danske offentlige aftaleorganisationer må siges at være stærke) og institutionelle ressourcer lokaliseret i fx aftalesystemets indretning og den beskrevne dobbeltrolle, hvorfra særligt de danske statslige arbejdsgivere henter magt. Derudover henvises der ofte til strukturelle magtressourcer. På det private arbejdsmarked lokaliseres disse fx i produktionens indretning, de økonomiske konjunkturer, beskæftigelsessituationen (Ibsen, 2015). I offentlig kontekst er denne også lokaliseret i andre fænomener såsom professionsrollen (Due og Madsen, 
2015). Denne ressource er vigtig på det offentlige arbejdsmarked og trækker på professionens evne til at dominere og ekskludere andre vidensgrupper fra eget vidensområde og arbejdsmarked. Offentlige lønmodtagergrupper kan blandt andet trække på deres professionelle viden i en diskursiv magtpositionering i den offentlige debat om $\mathrm{fx}$ velfærds- og forvaltningsreformer. De strukturelle magtressourcer kan således komme til udtryk som diskursive magtressourcer, om end fænomenet også har materielle aspekter (Levesque \& Murray, 2010).

Endelig har nyere litteratur understreget, at særligt den politiske magtressource i form af evnen til at vinde den offentlige opinion er afgørende for lønmodtagerne på det offentlige arbejdsmarked (Hansen og Seip, 2018; Schmidt et al., 2018, s. 4). Denne sidste magtressource er tæt forbundet med den diskursive magtressource, men er også afhængig af den gældende politiske kontekst - fx regeringens sammensætning og den generelle parlamentariske situation - som aftaleparterne agerer indenfor på et givent tidspunkt. Dette er reelt en ældre indsigt, som syntes at have fået fornyet betydning særligt efter den finansielle krise og presset på de europæiske velfærdsstater for at effektivisere og spare i den offentlige sektor (fx Bach and Bordogna, 2016; Ibsen et al., 2011; Schmidt et al., 2018). Dette er også forbundet med aktørernes og i dette tilfælde fagforeningernes og arbejdsgivernes evner til at anvende de forhåndenværende magtressourcer (Lévesque and Murray, 2010).

Nyere videnskabelige analyser af magt i den offentlige aftalemodel i Danmark har problematiseret navnlig de statslige arbejdsgiveres dobbeltrolle (Jacobsen og Pedersen, 2010; Mailand, 2014; 2015; Høgedahl, 2019). Om end disse studier også berør andre dynamikker, har de overvejende lagt vægt på de institutionelle magtressourcer, mens de politiske magtressourcer har fået mindre opmærksomhed. I forhold til den politiske magt mangler der blandt andet forståelse for, at muligheden for at sætte de ovennævnte forskellige magtressourcer i spil varierer alt efter den politiske kontekst på den politiske arena, hvor parterne forsøger at gøre sig gældende. Hermed understreger vi også, i tråd med klassik magtlitteratur, at det, som man har magt til - eller kan mobilisere magtressourcer til at realisere - ikke nødvendigvis er det, man vælger at gøre. 'Magt til' er således ikke det samme som, at 'tage magt over' (Lukes, 2005, s. 12, 34; Lévesque and Murray, 2010; Hansen, 2015; Hansen og Seip, 2018). At tage magt over har nemlig konsekvenser, og i en politisk kontekst kan sådanne både være på kort eller på længere sigt og være større eller mindre for de enkelte aktører. De politiske magtressourcer kan således også være mere eller mindre synlige alt efter den politiske kontekst.

I analysen herunder vil vi blandt andet diskutere aktørernes brug af forskellige magtressourcer under OK18 og forløbets betydning for forståelsen af magtbalancen i den offentlige aftalemodel i Danmark.

\section{Metode}

Metodisk trækker notatet på data fra både før, under og efter forhandlingerne. Fra perioden før forhandlingerne gik i gang, blev der gennemført interview med 15 forhandlerne, analyseret på dokumenter (breve udvekslet mellem parterne, køreplaner, rapporter, kravformulering mm.) og på parternes deltagelse i medierne. Under forhandlingerne blev der gennemført 37 telefonsamtaler og face-to-face møder med forhandlerne, lavet presseresuméer og indsamlet lækkede dokumenter, tweets, dagbøger og blogs. Efter forhandlingerne var afsluttet, blev der gennemført yderlige interview med 27 forhandlere og analyseret på forligstekster, evalueringer, udmeldinger i medierne, mm. Hvor intet an- 
det fremgår, er kilden til en given oplysning disse interview.

I Appendix A findes der en oversigt over interviewpersoner fra interviewene før forhandlingerne gik i gang, og efter forhandlingerne var afsluttede. Der refereres i artiklen ikke direkte til interview, telefonsamtaler og møder, da disse er udført under forudsætning af fortrolighed. Eliteinterview er i sig selv ikke en uproblematisk kilde til at studere proces og resultat i sammenhæng (Traxler, 2008). Men da vi har talt med flere repræsentanter om samme processer og derudover har analyseret dokumenter (herunder også lækkede dokumenter), har vi haft mulighed for at verificere aktørernes udsagn og triangulere.

\section{OK18 overenskomst- forhandlingerne baggrund og proces}

De svære forhandlinger cirklede omkring fire emner. Tre af disse fire temaer var velkendte allerede inden forhandlingsstart.

Det gjaldt for det første diskussionerne om den økonomiske ramme, der havde baggrund i OK15. Dengang italesatte de statslige arbejdsgivere, at der trods tidligere forsøg på at nedjustere lønudviklingen i det offentlige fortsat var en 'gæld'. Dette er også blevet benævnt 'løngabet'. Ved OK15 indførtes på den baggrund privatlønsværnet, der var en justering af reguleringsordningen i arbejdsgivernes favør. Lønmodtagernes forventninger til den økonomiske ramme var derimod påvirket af den generelt gunstige konjunkturudvikling og af de forlig, der var indgået under overenskomstfornyelsen i den private sektor i 2017.

Den anden knast var den betalte spisepause, som parterne længe havde været uenige om. Moderniseringsstyrelsen var af den opfattelse, at de lokale kutymer om betalt spisepause ikke var en del af de statslige over- enskomster, mens lønmodtagerne mente, at den betalte spisepause var en rettighed. Denne uenighed blussede op i efteråret 2017. Samarbejdet mellem lønmodtagerne og Moderniseringsstyrelsen havde derudover i en længere periode været præget af en række lokale sager, der havde reduceret de statslige lønmodtagerorganisationers tillid til arbejdsgiverne. Den betalte spisepausen blev ikke rejst af lønmodtagerne som et krav, men derimod som noget, man ville have 'betrygget', og det gerne forud for forhandlingerne. Da det ikke lykkedes, blev emnet en del af forhandlingerne.

Den tredje knast var loerernes arbejdstidsforhandlinger med baggrund i konflikten på undervisningsområdet under OK13, der understregede den statslige arbejdsgivers styrke som både arbejdsgiver og lovgiver i en konfliktsituation. Dette forløb - sammen med forløbet omkring den økonomiske ramme ved OK15 - havde direkte betydning for lønmodtagerorganisationernes ønske om at styrke koordineringen på tværs af bordene. Den 6. oktober sendte Forhandlingsfælleskabet (FF) og de statslige lønmodtagere i CFU et fælles brev til de offentlige arbejdsgivere, der beskrev, at 'arbejdsgivernes vilje til at indgå $i$ et reelt forhandlingsforløb' på underviserområdet ville blive tillagt stor betydning, for at kunne indgå generelle forlig på de tre aftaleområder (stat, kommuner og regioner).

Udover de tre knaster spillede skoevdeling i forhold til dagsordener om ligeløn/lavtløn og rekruttering også en central rolle ved forhandlingerne. Den 7. december udtog FF endeligt sine krav til forhandlingerne. Heraf fremgik det, at der var opnået enighed om at skævdele en begrænset del af den samlede økonomi til fordel for et ligeløns- og lavlønsprojekt. I tillæg hertil skulle det vise sig, at også de kommunale arbejdsgivere havde krav om skævdeling.

I forhold til baggrunden for OK18 er det også det vigtigt at nævne, at overens- 
komstforhandlingerne ramte ind i en generel utilfredshed blandt offentligt ansatte, som handlede om flere ting. Herunder utilfredshed med besparelser i det offentlige, for meget bureaukrati og manglende anderkendelse af de ansatte. Det er forhold, der ligger udover det, man diskuterer under overenskomstforhandlingerne. Men det var ikke desto mindre en utilfredshed, der gjorde det nemmere for lønmodtagersiden at mobilisere. Her kunne lønmodtagerne trække på deres diskursive magtressource, hvor offentligt ansatte fra overlæger til sosu-assistenter samlet set kritiserede forringelserne af arbejdspladserne og dermed rammerne for at levere velfærd.

Inden analysen skal processen her beskrives ultrakort: Første del af musketereden, der havde fokus på at sikre reelle forhandlinger om lærerenes arbejdstid, fik betydning allerede fra de første sættemøder. Herefter sattes alle andre forhandlinger på standby frem til den 22. januar, hvor LC meldte, at der nu var reelle forhandlinger. Først herefter startede forhandlingerne med forhandlingsfællesskaberne, nu under et vist tidspres. Forhandlingerne brød sidst i februar sammen først på det statslige område og dernæst på det kommunale og regionale område. I starten af marts overgik forhandlingerne derfor til Forligsinstitutionen. Det var første gang hele det offentlige område var i forligsinstitutionen på samme tid, og forhandlingerne var komplekse og langtrukne. Den første forlængelse af mæglingsprocessen var måske nok ventet, men op til den anden forlængelse i midten af april, vurderede flere af de centrale forhandlere, at Danmark var meget tæt på en storkonflikt. I dagene efter denne anden forlængelse af mæglingsbestræbelserne landede det første forlig den 25. april, og det meget utraditionelt på det regionale område. Dette såkaldte 'delforlig' indgik regionerne med LO-grupperne og en enkelt FTF-organisation, og det naglede den økonomiske ramme fast. Herefter forhandlede parterne videre og landede efter relativt kort tid forlig på alle andre områder. OK18 endte således noget overraskende med almindelige forhandlingsforlig - fremfor sammenkædede mæglingsforslag - som også efterfølgende blev stemt igennem med relativt stor stemmedeltagelse på nær for en enkelt mindre organisations vedkommende (Hansen \& Mailand, 2019).

\section{Musketereden og lønmodtagernes forhandlingsstrategi}

Musketereden blev vævet sammen i flere trin fra foråret 2017 og frem til kort før kravsudvekslingen, men der lå ingen egentlig masterplan bag. Efterhånden som de forskellige elementer blev kædet sammen, blev der dog dannet en slags samlet strategi, der handlede om at indløse en række bestemte lønmodtagerkrav, før man indgik forlig.

Musketereden havde baggrund i flere forhold. CFU ville af med hensigtserklæringen om at afvikle 'gælden' og af med privatlønsværnet, da CFU efter OK15 havde fortrudt, at de havde indgået aftaler om disse. På baggrund af arbejdsgivernes nu enslydende udspil på tværs af stat, kommuner og regioner i optakten til OK18 om endelig afregning af løngab og fastholdelse af privatlønsværnet - blev reallønsfremgang og afvikling af privatlønsværnet til en stærk fælles interesse på tværs af lønmodtagerorganisationerne.

LC havde behov for at gøre op med de gældende arbejdstidsbestemmelser, som var stort set identiske med Lov 409. Under konflikten i 2013 og igen i 2015 udviste de andre organisationer en begrænset solidaritet med lærerne i slutfasen af forhandlingerne. Men i forsommeren 2017 havde stemningen omkring lærernes arbejdstidsproblematik ændret sig, og det var tid til en ny strategi. Det var FOA's formand, som var ophav til ideen om en tidlig 'standby' med henblik på 
at fremskyde og sikre lærernes forhandlinger, før alle andre forhandlinger gik i gang. Denne del af musketereden skabtes fra juni til starten af oktober.

Kravet om skævdeling til fordel for ligeløn og lavtlønsgrupper var den del af musketereden, som sidst blev meldt ud til offentligheden. SHK, BUPL og SL etablerede et samarbejde med FOA, der havde en lignende dagsorden om ligeløn til deres lavtlønsgrupper. Samarbejdet resulterede i et fælles krav om intern skævdeling indenfor den økonomiske ramme i FF, som man handlede af internt i FF som modydelse for solidariteten med lærerne.

Akademikerne havde ønsker om en fritvalgskonto og havde også en udfordring med den betalte spisepause. Begge elementer blev en del af den fælles kravsudtagelse i FF, og var således handlet af med solidariteten med lærernes arbejdstid i form af den tidlige standby og med det fælles krav om skævdeling til ligeløn og lavtløn. Senere fulgte jobopslag i staten, der var rettet mod både akademikerog OAO-personale, hvor betalt spisepause var nævnt i sammenhæng med andre personalegoder. Et brev afsendt af Moderniseringsstyrelsen 9. oktober var også udslagsgivende for en fælles 'statslig' lønmodtagerforståelse af, at gjorde man ikke anskrig nu, ville man stå meget dårligt i en faglig voldgift senere. På den baggrund blev solidaritet omkring sikring af den betalte spisepause det afgørende og sidste element i musketereden.

Gennem musketereden etableredes først den såkaldte 'fembande' bestående af formænd repræsenterende FTF-K, OAO-K, FOA, SHK og Akademikerne indenfor FF. Den blev senere udvidet til 'seksbanden' med CFU og blev den centrale enhed, der koordinerede på tværs af stat, kommuner og regioner.

Skal man vurdere musketeredens betydning $i$ forhold til forhandlingsprocessen, så viste musketereden, at man stod sammen', og den var derved et stærkt udtryk for aktiveringen af den diskursive magt. På den måde havde den betydning for, at man kunne mobilisere tillidsrepræsentanter landet over og sandsynligvis også for, at man vandt den offentlige opinion. Den diskursive magt blev med andre ord transformeret til reel politisk magt. Det var særligt det sidstnævnte forhold, som var afgørende for presset på arbejdsgiverne. Som tidligere nævnt trak lønmodtagerorganisationerne i den sammenhæng også på en kontekst af større og mere generel utilfredshed blandt de offentlige lønmodtagere omkring besparelser i en offentlige sektor. En melding fra innovationsminister Sophie Løhde, der af nogle blev opfattet som, at hun mente, at de offentlige lønmodtagere fik for høj løn, hjalp også mobiliseringen på vej, da den blev spredt via de social medier.

Musketereden havde en del elastik indbygget i sine fire elementer, der skulle vise sig at være et tveægget sværd for lønmodtagerne i forhandlingerne. På den ene side gav elastikken lønmodtagerne fleksibilitet i forhold til at kunne forhandle. Men den gjorde det også svært at lande løsninger på de enkelte elementer, da man ikke kunne indgå kompromis ved et forhandlingsbord, uden at det ville have fået konsekvenser for de andre forhandlinger.

I forhold til lønmodtagernes formidling af musketereden var elastikken på samme måde tveægget. Elastikken var gavnlig, da man kunne mobilisere bredt på mange emner, men da søm skulle slås i, var sejren ikke entydig og let salgbar. Det stod fx ikke klart for alle, at det for LO-grupperne på det kommunale og regionale område alene var lønnen, der var det egentlige konfliktudløsende krav i musketereden, til trods for, at det var blevet meldt ud på et møde i FF den 2. marts. Skuffelsen var da også mærkbar hos en række af de øvrige lønmodtagereorganisationer, efter at det første delforlig blev indgået.

I forhold til forhandlingsresultaterne havde musketereden en væsentlig, men mere in- 
direkte betydning. Musketereden havde en mobiliserende effekt, men det var det samlede pres, der fik arbejdsgiverne til at flytte sig på den økonomiske ramme og andre emner. Selv da første forlig var landet, lykkedes det efterfølgende at sikre spisepausen mod moderat betaling, hvilket det samlede politiske pres i samspil med fastholdelsen af musketereden givet medvirkede til.

Musketereden spillede imidlertid en selvstændig rolle i forhold til de markante resultater på skævdelingerne indenfor den økonomiske ramme, som ellers ved tidligere overenskomstforhandlinger havde mødt stor intern modstand fra andre fagforeninger. I kraft af musketereden blev man enige om lavtløns- og ligelønsprojekterne, der blev finansieret med godt 0,02\% af den økonomiske ramme. Noget som de lønmodtagergrupper, der tilgodesås af dem, så som en vigtig markering med potentiale til at vokse i volumen på sigt. Rekrutteringspuljerne på det kommunale og regionale område indeholdt skævdeling på 0,3 \% af den økonomiske ramme. De kommunale arbejdsgivere havde en dobbelt interesse i at fremsætte krav om en rekrutteringspulje. Dels oplevede de en reel rekrutteringsudfordring, og dels havde de en interesse i at bryde musketereden op og skabe mulighed for alliancer med udvalgte grupper. Det var da også helt enestående, at der kunne skabes intern opbakning i FF relativt hurtigt til en så omfattende skævdeling. For at fastholde musketereden, og holde FOA indenfor fællesskabet, var accepten heraf simpelthen nødvendig.

\section{Arbejdsgivernes forhandlingsstrategi}

To elementer syntes at have været særligt vigtige i arbejdsgivernes forhandlingsstrategi: At forsøge at bryde musketereden op og at sikre stærk intern koordinering på arbejdsgiverside for at undgå selv at stå split- tet. Ingen af disse to forhandlingsstrategier trak på magtressourcer forbundet med den såkaldte dobbeltrolle.

Med hensyn til det første element, så var KL's formål med den omfattende rekrutteringspulje dels den officielt udmeldte, nemlig at imødegå rekrutteringsudfordringer, og dels en uofficiel interesse $i$ at skabe mulighed for alliancer med udvalgte grupper ved at tilbyde dem ekstra lønstigninger for indgåelse af forlig.

Ud over strategier for forhandlingsprocessen har parterne naturligvis også haft strategiske overvejelser i forhold til konfliktvarslerne, der blevet udformet i starten af marts måned. Det er navnlig i forhold hertil, at arbejdsgivernes dobbeltrolle kunne få betydning på sigt, men der er ikke tegn på, at deres strategiske overvejelser beroede på at udnytte denne. De meget omfattende lockoutvarsler kom som svar på lønmodtagersidens mere begrænsede strejkevarsler. Omend strejkevarslerne var begrænset til godt $10 \%$ af lønmodtagerne i den offentlige sektor, var udvælgelsen af områderne foretaget strategisk inden for hvert område, omend ikke nødvendigvis koordineret mellem organisationerne. Hvis strejkerne var blevet gennemført som varslet, havde de dog haft potentiale til at lukke store dele af den offentlige sektor.

De statslige arbejdsgivere overvejede i første omgang kortvarigt en mere afgrænset lockout. Men overvejelserne blev hurtigt lagt på hylden, og de statslige arbejdsgivere valgte den meget omfattende lockout. Det skyldtes, at det strategiske og offensive strejkevarsel i arbejdsgivernes optik ansporede til en bredere konflikt. Derudover kan der også have været et ønske om at korte konflikten ned ved at brede den ud til så godt som alle lønmodtagere. Et yderligere formål med det omfattende varsel var at sætte lønmodtagerorganisationerne og deres strejkekasser under pres. 
KL fulgte kort tid efter op på Finansministeriets lockout med et lockoutvarsel, der ligeledes var omfattende. KL havde i modsætning til Finansministeriet en officiel arbejdsgiverpolitik vedrørende lockout-varsler at henvise til. Denne politik foreskriver, at et strejkevarsel på et velfærdsområde i en enkelt kommune vil blive mødt med arbejdsgiversolidaritet og dermed med et landsdækkende lockoutvarsel på det pågældende område, hvis der sendes lockoutvarsel.

I Forligsinstitutionen forsatte arbejdsgiverne deres forsøg på at bryde musketereden op. I takt med at processen skred frem blev det stadig tydeligere, at det var med FOA og OAO-K på det kommunale og/eller regionale område, at chancerne for et gennembrud var størst. De statslige arbejdsgivere kontaktede da også både LO og FOA direkte med henblik herpå. I den forbindelse er det interessant, at arbejdsgiverne endte med at give køb på privatlønsværnet. Hos både de kommunale og de statslige arbejdsgivere var der en erkendelse af, at privatlønsværnet var en klods om benet på CFU-formanden og svækkede ham som forhandlingsleder, hvilket heller ikke for arbejdsgiverne var en fordel. Der var desuden - også blandt nogle af de statslige arbejdsgiverforhandlere - skepsis i forhold til, hvor god en konstruktion privatlønsværnet var. Man var angiveligt længe, inden det skete, indstillet på at opgive det på et strategisk gunstigt tidspunkt i forhandlingerne.

Dette strategiske tidspunkt skulle vise sige at være efter 2 . udsættelse af konfliktvarslet. Som med andre indrømmelser fra både arbejdsgiverne og for lønmodtagerne er det markant, at denne indrømmelse først kom efter lang tid i forligsinstitutionen, og efter at de fleste forhandlere havde regnet med, at parterne var endt i konflikt.

Et særligt aspekt af arbejdsgivernes strategi var koordineringen mellem de tre arbejdsgivere. Der er ingen tvivl om, at koordineringen generelt er tæt. Under og efter OK13 kom der særligt fokus på denne koordinering med beskyldningerne om aftalt spil i forbindelse med lærerkonflikten.

Også ved OK18 var koordineringen tæt, men OK18 viste, at der er grænser for koordineringen. I forhandlingerne om lærernes arbejdstid havde LC en oplevelse af, at koordineringen var så tæt, at imødekommelser fra KL's forhandlere blev trukket tilbage, når KL's forhandlere efterfølgende havde været i kontakt med Moderniseringsstyrelsen. LC's oplevelse medvirkede til, at LC i medierne tegnede et billede af KL-forhandlere, der ønskede at være mere imødekommende og mere stejle statslige arbejdsgivere som holdt igen. Denne udlægning har parterne på den anden side af bordet ikke kunnet bekræfte, og på lønmodtagersiden har nogle af organisationerne også haft en oplevelse af en mindre tæt koordinering, end den LC gav udtryk for. Så billedet er ikke tydeligt. Hvad der står mere klart er, at de statslige arbejdsgivere ville undgå, at KL kom med indrømmelser på folkeskoleområdet, som ville få utilsigtede negative konsekvenser på de statslige undervisningsområder.

Et andet punkt, der kan bidrage til en diskussion af tætheden i koordineringen og hierarkiets tydelighed, er KL's introduktion i slutningen af februar af en lønmodel baseret på det private forlig i stedet for på den skønnede lønudvikling. Sammen med introduktionen af denne model forsvandt også KL's referencer til 'løngabet', omend KL tilsyneladende implicit i en efterfølgende periode stadig medregnede løngabet i deres udspil. KL forelagde angiveligt denne alternative model for de statslige arbejdsgivere i slutningen af januar. Efter at have regnet på modellen, endte de statslige arbejdsgivere med at afvise modellen, da de mente, den indebar for høje lønninger. Men KL holdt fast og bad i starten af februar om at få mandat til modellen i Kommunernes Lønningsnævn (KLN), hvor Finansministeriet 
er repræsenteret. Finansministeriet fastholdt deres nej, men da de ikke har vetoret, fik KL deres mandat alligevel. I det parallelle RTLN på det regionale område har de statslige repræsentanter imidlertid vetoret, og det ville derfor ikke på dette område kunne lade sig gøre at komme igennem med noget, som den statslige arbejdsgiver ikke ønskede.

Et tredje eksempel på grænser for koordineringen var den ovenfor nævnte omfangsrige kommunale rekrutteringspuljer. Den kommunale rekrutteringspulje var en afgørende del af KL's strategi på det kommunale område. Her er det bemærkelsesværdigt, at de regionale såvel som de statslige arbejdsgivere fremførte, at rekrutteringspuljen ikke var koordineret med dem, og at de først hørte om dem ved kravsudvekslingen i starten af december.

\section{Det politiske system}

De offentlige aftaleforhandlinger er kendetegnet ved et tæt samspil med det politiske system og har grundlæggende en politisk karakter. Dels var der under OK18 synlige forsøg på politisk påvirkning af forhandlingerne, hvor Folketingspolitikere fra regering eller opposition i offentligheden kom med meldinger, der direkte eller indirekte relaterede sig til forhandlingerne. Dels foregik der en mere lukket politisk påvirkning, hvor politikere og forhandlere indgik i et samspil uden for mediernes synsfelt.

Med hensyn til den åbne interaktion er det typisk - og ikke overraskende - under de mere konfliktfyldte overenskomstforhandlinger, som i 2013 og i 2018, at udmeldinger om forhandlingerne fra politikerne fylder mest. Under OK13 var det de politiske partier $i$ regeringen, der var mest aktive $i$ at komme med åbne udmeldinger under forhandlingerne. Under OK18 var det omvendt i høj grad oppositionspolitikere (med Socialdemokratiet bemærkelsesværdigt fraværende i en lang periode), der markerede sig med udmeldinger, der på forskellig vis havde til formål at påvirke forhandlingerne og/eller at sende beskeder til vælgerne.

Den åbne påvirkning begyndte allerede i december, hvor SF's Jacob Mark stillede spørgsmål til Beskæftigelsesministeren for at sikre ministerens garanti for fair og fri forhandlinger under OK18.

Da deadline for den ordinære forhandlingsfase nærmerede sig uden tegn på forlig, begyndte flere af de politiske partier at lade høre fra sig. Der var udmeldinger fra bl.a. Enhedslisten, SF, Alternativet og De Radikale. Mest opmærksomhed fik det, da Dansk Folkepartis formand på KL's topmøde i Aalborg opfordrede de offentlige arbejdsgivere til imødekommenhed ved forhandlingsbordet, og i den forbindelse udtalte, at der var 'en bodsgang at gå' i forhold til lærerne, som han mente blev kørt fuldstændig over ved sidste konflikt (tv2.dk 8. marts 2018).

Senere på måneden begyndte partierne at beskylde hinanden for politisk indblanding og hykleri (Informationen 21. marts 2018; Jyllandsposten 21. marts 2018).

Efter forligsmandens 1 . udsættelse af konfliktvarslet blev meldingerne fra politikerne færre, men den 11. april kundgjorde statsministeren, at regeringen ikke ville anvende sparede midler fra en eventuel konflikt vilkårligt, men ville i stedet oprette en velfærdspulje. Forslaget fik udstrakt opbakning både fra Dansk Folkeparti og fra flere oppositionspartier (Jyllandsposten 11.april).

Der kan være forskellige effekter af sådanne åbne udmeldinger, og nogle politiske meldinger vil sandsynligvis have mere konkrete effekter end andre. Folketingspolitikernes udmeldinger påvirker dels den offentlige opinion, der er et vigtigt redskab under overenskomstfornyelser i den offentlige sektor. Dette gælder især, når de som OK18 ligger relativt tæt på et valg, fordi politikerne da forventer, at vælgernes tilfredshed 
eller utilfredshed med politikernes ageren under overenskomstfornyelsen vil smitte af på afstemningsresultatet. Dels kan politikernes udsagn i en konfliktfyldt overenskomstfornyelse fungere som signaler om, hvad et politisk parti vil arbejde for, hvis det skulle komme til et lovindgreb. Flere af de ovenstående udsagn kan have haft den funktion. Blandt disse var de mest markante nok udmeldingerne fra SF, De Radikale og Dansk Folkeparti om lærernes arbejdstid, der meget vel kan have styrket LC i forhandlingerne og have øget LC's krav under forhandlingerne om en arbejdstidsaftale med KL. Der er således også et rum her, hvor lønmodtagerorganisationerne har mulighed for at spekulere $\mathrm{i}$ dobbeltrollen, såfremt den parlamentariske situation tillader det.

Ud over denne åbne interaktion, foregik der - som der altid i et vist omfang gør ved de offentlige overenskomstforhandlinger en mere lukket interaktion mellem forhandlere og politikere. Denne type af interaktion er sværere at afdække end den åbne, da det sjældent er i aktørernes interesse at blotlægge denne fuldstændigt - heller ikke efter at forhandlingerne er afsluttede. Men der kan alligevel godt siges lidt om nogle elementer heraf fra OK18. På trods af at det ikke kom til lovindgreb, kom regeringen som politisk aktør ifølge nogle af vores arbejdsgiverinformanter til at spille en rolle, da der mod slutningen af forløbet kom meldinger fra regeringens koordinations- og økonomiudvalg om, at der skulle findes en løsning på spisepausen, blandt andet fordi spisepausen ikke var et egnet emne at tage en konflikt på for arbejdsgiverne. Det er vores tolkning, at arbejdsgivernes pris for en løsning på spisepausen dermed reduceredes, og at dette kan have været en medvirkende faktor til, at forlig blev muligt. Og det er sandsynligt, at regeringens manglende lyst til at kaste sig ud i en konflikt med trekvart million vælgere på et tidspunkt, hvor næste folketingsvalg lå maximalt godt et år væk, har været en afgørende faktor for at regeringens top kom med denne melding om spisepausen.

\section{Forligsinstitutionen}

Forligsinstitutionen kom som beskrevet ovenfor til at spille en større rolle under OK18 end sædvanligt under den offentlige sektors overenskomstfornyelser.

OK18 viste, at Forligsinstitutionen kunne levere, men der har været kritik af det langstrakte forløb og overvejelser om, hvorvidt intuitionen har nok ressourcer til at håndtere så mange organisationer, som var til stede under OK18. I forhold til sidstnævnte, kom også hovedorganisationerne - og her navnlig LO - til at spille egne roller. Det lykkedes parterne selv at indgå forlig i Forligsinstitutionen, og de valgte, under indflydelse fra særligt LC og 3F, at sende disse til almindelig afstemning.

Ved de fleste overenskomstfornyelser i den offentlige sektor spiller lønmodtagernes hovedorganisationer - med Akademikerne som undtagelse - stort set ingen rolle. Der er fx ikke som i den private sektor tradition for sammenkædning, hvor hovedorganisationerne kommer på banen. Det er fællesskaberne CFU og FF, de enkelte organisationer og disses grupperinger inden for CFU og FF, der er de væsentlige aktører på lønmodtagersiden. Men også på dette punkt blev OK18 anderledes.

Ifølge forligsmandsloven er det hovedorganisationerne, der har kompetencen, når forhandlingerne overgår til forligsinstitutionen. Men reelt overdrager LO og FTF kompetencen til forhandlingsfællesskaberne. FTF overdrog kompetencen til SHK-formanden på det regionale område, og FF/LC-formanden på det kommunale og statslige område. FTF-formanden var, efter anmodning fra nogle af FTF's organisationer, fra et tidligt tidspunkt i forløbet til stede i Forligsinsti- 
tutionen. Angiveligt har formandens rolle været at understøtte det interne sammenhold i FTF-gruppen, deltage i drøftelser af strategien, have uformelle drøftelser med organisationerne uden for FTF og derudover føre samtaler med forligsmanden. Men FTF-formanden deltog ikke selv i møderne mellem forhandlingsfællesskaberne og modparterne og/eller forligsmanden. LO overgav deres bemyndigelse til CFU-formanden på statens område og til FOA-formanden på det kommunale og regionale område. LO's bemyndigelsesbreve understreger $\mathrm{dog}$, at forligsmanden fortsat kan rådføre sig med LO-formanden. LO-formanden var så vidt vides ikke fysisk tilstede i Forligsinstitutionen, og spillede en anden rolle end FTF-formanden. Der var kontakter mellem LO og forligsmanden igennem hele forløbet. Særligt i forbindelse med forligsmandens beslutning om at forlænge konfliktvarslet anden gang, har LO-formanden tilsyneladende haft samtaler med Forligsmanden. Men der er forskellige udlægninger af dette forløb, og også andre aktører kan have spillet en rolle i denne beslutning.

LO spillede derudover også en rolle ved at bidrage med juridisk vejledning af de forhandlende LO-organisationer. Det drejede sig bl.a. om vejledning i forhold til etablering af konfliktberedskabet. Men omdrejningspunktet for vejledningen var især spørgsmålet om spisepausen, og vejledningen havde indflydelse på beslutningen om, hvilket niveau af 'betryggelse' (dvs. hvorvidt bestemmelserne var arbejdsretsligt bindende) FOA og OAO-K var villige til at acceptere som en del af deres forlig.

Forløbet har ansporet til en debat om, hvordan fremtidig koordination i forligsinstitutionen kan foregå. Forløbet viste, at parterne selv magtede en stor del af koordineringen, men også at institutionen stod svagt i forhold til fx at håndhæve reglerne om tavshed under mæglingsbestræbelserne. Grundet det afgørende politiske magtspil fandt både lønmodtagere og arbejdsgivere det nødvendigt at forhandle ud af vinduerne $i$ et hidtil uset omfang. Spillet om den politiske magt gør således Forligsinstitutionens rolle besværlig.

\section{Diskussion: OK18 og magtbalancen}

Udfordringerne for det offentlige aftalesystem er som nævnt i dansk forskning navnlig blevet begrebsliggjort i form af det ulige magtforhold, og særligt de statslige arbejdsgiveres såkaldte dobbeltrolle.

Den nyere historie i det offentlige aftalesystem i Danmark bekræfter umiddelbart det ulige magtforhold. Særligt lockouten på undervisningsområderne i 2013 viste, at dobbeltrollen kan være et stærkt magtmiddel for arbejdsgiverne. Ved OK13 ville arbejdsgiverne have ændret lærernes arbejdstidsbestemmelser fundamentalt, og det kom til at ske igennem en frigørelseskonflikt. Dobbeltrollens betydning blev først for alvor synlig, efter at det blev klart, at arbejdsgiverne ikke var indstillet på et indholdsmæssigt kompromis, men kun på en kompensation, som LC ikke var interesseret i (Mailand, 2014). Dette resulterede i, at Forligsinstitutionen ikke kunne spille sin rolle og mægle mellem parter, da der ikke var grundlag for kompromis. Dermed var der skabt en situation, hvor der ikke var noget fra forhandlingerne eller fra mægling, man kunne bygge et balanceret lovindgreb på. Da lovindgrebet stemtes igennem i Folketinget, var det derfor med arbejdstidsbestemmelser for lærerne formuleret af embedsmænd inden for selvsamme statslige system, som sammen med KL havde frigjort sig fra de tidligere forhandlede bestemmelser. Det illustrerede, at hvad de offentlige arbejdsgivere ikke kan få igennem 
ved forhandlingsbordet, kan de efterfølgende få igennem ved konflikt og lovindgreb, hvis der kan etableres et politisk flertal herfor i Folketinget.

Efter OK13 var der debat - dog overvejende internt blandt lønmodtagerorganisationerne - om magtasymmetrien og dobbeltrollen (Hansen, 2015; Høgedahl og Ibsen, 2015; Mailand, 2014; Kristiansen, 2015; Sorgenfrey, 2015; Vinther, 2015). Navnlig tre forhold var til diskussion fra tiden kort efter OK13 (Mailand, 2014): For det første en diskussion om, hvorvidt Forligsinstitutionen kan styrkes og den statslige hovedforhandler, som traditionelt er den siddende finansminister, kan tvinges til at deltage og sikre mæglingsbestræbelsen. For det andet blev det direkte foreslået at adskille finansministeriets politiske og arbejdsgiverrolle strukturelt med inspiration fra det svenske 'Arbetsgivarverket'. Endelig blev det diskuteret, hvorvidt lockoutvåbnet kan tæmmes fx ved at lade eventuelle sparede lønkroner ved lockout løbe tilbage til det velfærdsområde, hvor konflikten er ført. Derudover er det blevet fremført, at de offentlige lønmodtageres lyst til strejke er anderledes motiveret, da de ikke på samme måde, som privatansatte, der arbejder i internationalt konkurrenceudsatte sektorer, risikerer arbejdspladser gennem strejkeaktivitet.

Meget af denne diskussion ebbede hurtigt ud, og arbejdsgiverne var generelt tilbageholdende med at deltage i den (se dog arbejdsgiverindlæg i temanummer af tidsskriftet Økonomi og Politik, Vol. 88, No. 4). Men lønmodtagernes mobilisering ved OK18, og særligt publiceringen af en rapport med komparativ analyse af de nordiske aftalesystemer (Høgedahl, 2017) under optakten til OK18, genoplivede diskussionerne. ${ }^{2}$

Overordnet har alle diskussionerne siden OK13 været præget af en opfattelse af, at de statslige arbejdsgiveres dobbeltrolle er det, der afgør magtbalancen mellem de offentli- ge arbejdsgivere og lønmodtagere, og ovennævnte forslag har handlet om at tæmme særligt de statslige arbejdsgiveres institutionelle magt ved at gennemføre institutionelle forandringer. Det gælder også forslagene fremsat i ovennævnte rapport (Høgedahl, 2017). Men som det fremgår af vores analyser af henholdsvis lønmodtagernes og arbejdsgivernes strategier, så viser OK18 imidlertid, at selvom de institutionelle forhold naturligvis har stor betydning, så definerer de ikke alene magtbalancen.

OK18 demonstrerede for det første, at de offentlige lønmodtagere internt kan styrke deres forhandlingsposition ved at koordinere på tværs, mens de statslige arbejdsgivere måske ikke altid evner at spille den altdominerende rolle. Som beskrevet ovenfor havde musketereden stor betydning for mobilisering af tillidsrepræsentanter og fagligt aktive på tværs af hele det offentlige område. Den havde også betydning for at opnå forståelse i den bredere offentlighed, og har dermed også haft en rolle i at skabe det politiske pres på de offentlige arbejdsgivere. Lønmodtagerorganisationerne styrkede med andre ord deres egen magtposition ved at stå sammen og koordinere på tværs. Sammenholdet muliggjorde også, at lønmodtagerne kunne trække på diskursiv magt og udnytte den kombinerede professionelle position, som sygeplejersker, lærere, læger, dommere mv. har i samfundet, når de samlet siger, 'at nok er nok', og vi står 'skulder ved skulder'. OK18 processen satte samtidig spørgsmålstegn ved de statslige arbejdsgiveres reelle evne til at styre internt. Særligt fraværet af statslig vetoret i de kommunale forhandlinger giver de kommunale arbejdsgivere et manøvrerum, som blev brugt ved OK18, om end der fortsat er tale om tæt koordinering mellem arbejdsgiverne.

For det andet så viste OK18, at der ligger væsentlige magtressourcer gemt i navnlig interaktionen med det politiske system. De 
offentlige lønmodtagere mobiliserede ved OK18 politiske magtressourcer i et større omfang end set længe. Dette kunne lade sig gøre i den særlige politiske kontekst som OK18 forløbet udspillede sig i. Ved OK18 var det i modsætning til ved OK13 lønmodtagerne, som ganske entydigt vandt den offentlige opinion. Det gav en afgørende anderledes dynamik i forhandlingerne særligt i forhold til det politiske system, hvor det yderligere spillede ind, at det næste Folketingsvalg ikke var langt væk.

Tilsammen skabte disse to ting et stærkt politisk pres, hvor politikerne på kort sigt kunne øjne de politiske omkostninger ved at lægge sig ud med en stor del af den danske arbejdsstyrke. Dette samlede politiske pres medvirkede til, at regeringens top undervejs i forligsinstitutionen valgte at give sig på lønkrav og krav om spisepausen. Som det fremgik af afsnittet om det politiske system, fik lønmodtagerne derudover også undervejs en vis opbakning fra politikere på Christiansborg. I tiden, hvor parterne var i Forligsinstitutionen, blev det klart, at et lovindgreb i modsætning til under OK13, for at kunne opnå flertal i Folketinget, sandsynligvis skulle leve op til krav rejst af partier uden for regeringen. Dels var den parlamentariske situation en anden under OK18 med en liberal-konservativ mindretalsregering, som det var nemmere for fagbevægelsen at skabe et fjendebillede omkring. Dels kunne man som nævnt ovenfor allerede året efter OK18 se frem til et valg. Et indgreb ville derfor ikke blot blive svært for den siddende regering, men også for Socialdemokratiet, hvis de lagde stemmer til et indgreb, der ikke i tilstrækkelig grad imødekom de offentligt ansatte.

OK18 pegede således helt entydigt på, at lønmodtagernes samlede magtressource i de offentlige aftaleforhandlinger også beror på, at der kan skabes et politisk pres på arbejdsgi- verne, og at det i den forbindelse er afgørende at vinde den offentlige opinion. Medierne, også de sociale medier, var vigtige våben $\mathrm{i}$ kampen om denne. Det er den konkrete baggrund for de mange tweets og læk ud fra både de ordinære forhandlinger og - hvad værre er - fra forligsinstitutionen. Sidstnævnte er i direkte modstrid med Forligsmandsloven. Derudover er denne form for 'forhandling ud af vinduerne' også problematisk i forhold til at kunne opnå resultater ved forhandlingsbordet. Det modvirker, at parterne kan forelægge nye kreative løsningsforslag af frygt for, at de vil blive afsløret og brugt imod dem i medierne. Selvom der således var læk på begge sider fra forligsinstitutionen, er det dog klart fagbevægelsen, der er flittigst med 'at forhandle ud af vinduerne'. Det skyldes, at de grundlæggende er mere afhængige af, at kunne mobilisere offentligheden for at skabe politisk pres på arbejdsgiverne end omvendt.

Et andet våben lønmodtagerne trak på, var den direkte interaktion med politikerne. Indblanding fra politikere - eller at parterne kalder på politikerne - under aftaleforhandlingerne er generelt anskuet som illegitimt i det danske aftalesystem. Alligevel er det et udbredt fænomen. Det er dog et grundlæggende dilemma i det offentlige aftalesystem, at parterne for at vinde magt ved forhandlingsbordet mener de er nødsaget til at anvende medier og politikere i så stort omfang, som det skete ved OK18, samtidig med at de selv anser selvsamme handlinger for illegitime og i øvrigt også reelt vanskeliggør forhandlingerne.

Hvor diskussionerne om magtbalancen i det offentlige aftalesystem tidligere har fokuseret meget på dobbeltrollen og de institutionelle magtressourcer, så viste $\mathrm{OK} 18$, at magtbalancen også er afhængig af den politiske kontekst og lønmodtagernes mulighed for mobilisering. De politiske omkostninger ved konflikt i det offentlige aftalesystem er 
altså - også på grund af dobbeltrollen - reelle for de statslige arbejdsgivere.

\section{Konklusion}

I denne artikel har vi analyseret aftaleparternes strategier, samt betydningen af interaktionen med både det politiske system og Forligsinstitutionen. På baggrund heraf har vi nuanceret forståelsen af magtbalancen mellem arbejdsgiver og lønmodtagere i den offentlige aftalemodel.

Forhandlingsprocessen ved OK18 var exceptionelt langtrukken, og ved den 2 . udsættelse af konfliktvarslet var det ganske tæt på en storkonflikt. Formuleret kort, så kan den ekstraordinære proces og resultaterne ved OK18 forklares med musketereden og fagbevægelsens succesfulde mobilisering af kernetropper og befolkning, samt en parlamentarisk situation med en borgerlig regering og et forestående folketingsvalg, hvor et lovindgreb ikke så nemt ud. Musketereden og fagforeningernes mobilisering var en reaktion på, hvad lønmodtagerne opfattede som urimelig ageren fra arbejdsgivernes side ved især OK13 og OK15, og hvad lønmodtagerorganisationerne anså for forsøg på øget ledelsesrum på bekostning af velerhvervede lønmodtagerrettigheder, og urimelige lønkrav under OK18.

Med hensyn til OK18s resultater kan musketereden, mobiliseringen og det forestående valg være med til at forklare, at lønmodtagerne kom relativt godt ud af overenskomstfornyelsen i den forstand, at både løngabsdiskussionen og privatlønsværnet forsvandt, og at der blev fundet løsninger på spisepausen for en lav pris. Men OK18-forligene indeholder ikke store nyskabelser eller nye perspektiver i forligene, men har snarere karakter af at vedligeholde eksisterende rettigheder. Succesen for lønmodtagerne, i det omfang man kan tale om en sådan, handlede altså for lønmodtagerne mere om afvikling af tidligere problemelementer og beskyttelse mod nye forringelser. OK18 havde således trods det høje konfliktniveau og lønmodtagernes aktive mobilisering mere karakter af en defensiv kamp om indhold end en offensiv.

Betydningen af det politiske pres ved OK18 er uomtvistelig. På baggrund heraf, og på baggrund af nye indsigter i lønmodtagernes og arbejdsgivernes evner til at koordinerer internt, må antagelsen om det såkaldte asymmetriske magtforhold tages op til revision. Dobbeltrollen fokuserer alene på arbejdsgivernes magtressourcer og det endda snævert for de statslige arbejdsgivere. Vi afviser ikke at magtforholdet er asymmetrisk, men OK18 illustrerede tydeligt, at fagbevægelsens politiske magtressourcer i Danmark kan være betydelige, hvis de udnyttes rigtigt og den politiske kontekst er den rette. I forhold til en styrket magtbalance forståelse i den offentlige aftalemodel er det således afgørende, at denne ikke alene er afhængig af den institutionelle indretning af aftalemodellen, men også af aktørernes mulighed for at interagerer med det politiske system og mobilisere den bredere befolkning.

Ved OK18 var det særligt det forestående valg, samt den herskende parlamentariske situation, som var afgørende for muligheden for mobilisering. Der var tale om en liberal konservativ mindretalsregering, som det var nemt at skabe et fjendebillede omkring, samt et Socialdemokrati, som have behov for at skabe afstand til begivenhederne ved OK13. At sådanne politiske rammevilkår har betydning er en klassisk indsigt fra den internationale litteratur, som syntes at være glemt i dansk arbejdsmarkedsforskning.

OK13 syntes at vise, at der umiddelbart var få politiske omkostninger forbundet med konflikt på det offentlige område. OK18 fortæller det modsatte. Politiske omkostnin- 
ger for de offentlige arbejdsgivere er reelle, men kontekstafhængige. Det betyder også, at de kan være tydlige på kort sigt som ved OK18, eller først blive tydelige på længere

\section{REFERENCER}

Bach, S. \& Bordogna, L. (Eds.) (2016). Public Service Management and Employment Relations in Europe: Emerging from the Crisis? London: Routledge. https://doi.org/10.4324/9781315724096.

Due, J. \& Madsen, J. S. (1996). Forligsmagerne. København: Jurist og Økonomforbundets Forlag.

Due, J. \& Madsen, J. S. (2015). Fra tjenestemænd til overenskomstansatte - en historisk analyse af konfliktformer i det offentlige aftalesystem. Økonomi og Politik, 88(4), 64-75. https://www.djoef-forlag.dk/openaccess/oep/ files/2015/4_2015/4_2015_9.pdf

Flanders, A. (1970). Management and Union. London: Faber \& Faber.

Hansen, N. W. \& Seip, Å. A. (2018). Government employers in Sweden, Denmark and Norway: The use of power to control wage and employment conditions. European Journal of Industrial Relations, 24(1), 73-89. https:// doi.org/10.1177/0959680117708371.

Hansen, N. W. (2016). Statslige arbejdsgivere mellem politik og voluntarisme i Danmark og Sverige. I T. P. Larsen \& A. Ilsøe (Eds.), Den danske model set udefra. Komparative perspektiver på dansk arbejdsmarkedsregulering. København: Jurist og Økonomforbundets Forlag.

Hansen, N. W. (2015). De statslige arbejdsgivere i Danmark og Sverige og deres magt. Økonomi og Politik, 88(4), 76-87. https:// www.djoef-forlag.dk/openaccess/oep/files/2015/4_2015/4_2015_10.pdf

Hansen, N. W. \& Mailand, M. (2019). Overenskomstfornyelsen 2018. Musketered, magtbalancer og modelforandringer. FAOS Rapport, Nr. 166. København: Sociologisk Institut, Københavns Universitet. https://faos.ku.dk/ publikationer/forskningsnotater/rappor- sigt. OK13 har således først på sigt tydeligt påvirket flere politiske partiers handlemuligheder herunder også Socialdemokratiet ved OK18.
ter-2019/Rapport_166_-_Overenskomstfornyelsen_2018.pdf

Høgedahl, L. (2019). Den danske model i den offentlige sektor. Danmark $i$ et nordisk perspektiv. København: Djøf Forlag.

Høgedahl, L. (2017). Offentlige overenskomstforhandlinger og konfliktløsning - Danmark i et nordisk perspektiv. Forskningsrapport. CARMA: Institut for Statskundskab, Ålborg Universitet, Ålborg.

Høgedahl, L. \& Ibsen, F. (2015). Konfliktrettens anvendelighed i den offentlige sektorset i lyset af OK 2013. Økonomi og Politik, 88(4), 3450. https://www.djoef-forlag.dk/openaccess/ oep/files/2015/4_2015/4_2015_7.pdf

Højsgaard, L. (2018). Fagbevægelsen havde en hemmelig OK18-masterplan - læs om den her. Journalisten.dk 08.06.2018, 13:17.

Jacobsen, K. \& Pedersen, D. (2010). Kampen om den danske model. Da sosu'erne rystede det etablerede system. København: Informations Forlag.

Kelly, J. (2011). Theories of collective action and union power. I G. Gall, A. Wilkinsson $\&$ R. Hurd (Eds.), The International Handbook of Labour Unions. Reponses to Neo-Liberalism (pp. 13-28). Cheltenham Glos: Edward Elgar Publishing. https://doi.org/10.4337/9780857 938053.00006.

Kristiansen, J. (2015). Konfliktret på det offentlige arbejdsmarked. Økonomi og Politik, 88(4), 51-63. https://www.djoef-forlag.dk/openaccess/oep/files/2015/4_2015/4_2015_8.pdf

Ibsen C. L., Larsen, T. P. \& Madsen, J. S. (2011). Challenging Scandinavian employment relations: The effects of new public management reform. International Journal of Human Resource 
Management, 22(11), 2295-2310. https://doi. org/10.1080/09585192.2011.584392.

Ibsen, C. L. (2015). Three approaches to coordinated bargaining: A case for power-based explanations. European Journal of Industrial Relations, 21(1), 39-56. https://doi.org/10.1177/0959680114527032

Lévesque C. \& Murray, G. (2010). Understanding union power: resources and capabilities for renewing union capacity. Transfer, 16(3), 333-350. https://doi. org/10.1177/1024258910373867.

Lukes, S. (2005). Power. A Radical View. Houndmills, Basingstoke: Palgrave Macmillan.

Mailand, M. (2014). Overenskomstforhandlinger under pres - OK2013 i den offentlige sektor. København: Sociologisk Institut, Københavns Universitet. https://faos.ku.dk/pdf/ boger-og-rapporter/2014/Overenskomstforhandlinger_under_pres.pdf

McAdam, D. (2004). Conceptual Origins, Current Problems, Future Directions. I D. McAdam, J. D. McCarthy \& M. N. Zald (Eds.), Comparative Perspectives on Social Movements. Political Opportunities, Mobilization Structures and Cultural Framing (pp. 25-40). Cambridge: Cambridge University Press.
Pedersen, D. (1993). Offentlig løn. Projekt forhandlingsøkonomi. Samfundslitteratur: Frederiksberg.

Petersen, H. (1987). Ledelse og loyalitet - kollektiv arbejdsret $i$ den offentlige sektor. København: Akademisk Forlag.

Sorgenfrey, B. (2015). Hvad lærte vi af OK 2013? Økonomi og Politik, 88(4), 3-7. https:// www.djoef-forlag.dk/openaccess/oep/files/2015/4_2015/4_2015_2.pdf

Schmidt, W., Müller, A., Ramos-Vielba, I., Thörnquist, A. \& Thörnqvist, C. (2018). Austerity and public sector trade union power: Before and after the crisis. European Journal of Industrial Relations, 37, 1-17. https://doi. org/10.1177/0959680118771120.

Traxler, F., Brandl, B. \& Glassner V. (2008). Pattern Bargaining: An Investigation into its Agency, Context and Evidence. British journal of Industrial Relations, 46(1), 33-58. https:// doi.org/10.1111/j.1467-8543.2007.00664.x.

Vinther, F. (2015). Den danske model vil overleve så længe viljen er der. Økonomi og Politik, 88(4), 13-17. https://www.djoef-forlag.dk/openaccess/oep/files/2015/4_2015/4_2015_4.pdf

Wright, E. O. (2000). Working-class power, capitalist-class interests, and class compromise. American Journal of Sociology. 105(4), 957-1002. https://doi.org/10.1086/210397.

dobbeltrollen, der refererer til en arbejdsgiver og mere udefineret politisk rolle.

2. Rapporten er senere omskrevet til bog (Høgedahl 2019) 


\section{BILAG}

\begin{tabular}{|c|c|}
\hline Finansministeriet & $\begin{array}{l}\text { Innovationsminister Sophie Løhde } \\
\text { Departementschef Martin Præstegård } \\
\text { Rådgiver for Innovationsminister Thomas Bille Winkel }\end{array}$ \\
\hline Moderniseringsstyrelsen & $\begin{array}{l}\text { Direktør Poul Taarnkvist } \\
\text { Vice-direktør Linda Nordstrøm Nissen }\end{array}$ \\
\hline KL & $\begin{array}{l}\text { Formand KL's Løn- og Personaleudvalget Michael Ziegler } \\
\text { Direktør Kristian Heuniche } \\
\text { Kontorchef Louise Koldby Dalager } \\
\text { Kontorchef Charlotte Hougaard Clifford }\end{array}$ \\
\hline DR & $\begin{array}{l}\text { Formand Regionernes Lønnings- og Takstnævn } \\
\text { Anders Kühnau } \\
\text { Forhandlingsdirektør Signe Friberg } \\
\text { Kontorchef Ole Lund Jensen }\end{array}$ \\
\hline CFU & $\begin{array}{l}\text { Forbundsformand HKKF Flemming D. Vinther } \\
\text { CFU-sekretær (fra 1.1.18) Mikael Jespersen } \\
\text { CFU- sekretær (til 1.1.18) Janus Bro Malm }\end{array}$ \\
\hline $\mathrm{FF}$ & $\begin{array}{l}\text { Sekretariatschef Helle Krogh Basse } \\
\text { Vicesekretariatschef Henrik Würtzenfeld }\end{array}$ \\
\hline $\mathrm{FF}, \mathrm{LC} / \mathrm{DLF}$ & $\begin{array}{l}\text { Forhandlingsleder for FF og LC } \\
\text { Anders Bondo Christensen }\end{array}$ \\
\hline LC/DLF & $\begin{array}{l}\text { Formand for overenskomstudvalget } \\
\text { Gordon Ørskov Madsen }\end{array}$ \\
\hline Akademikerne & Direktør Sine Sunesen \\
\hline FAS & Direktør Kasper Axel Nielsen \\
\hline Yngre Læger & $\begin{array}{l}\text { Formand Camilla Noelle Rathcke } \\
\text { Forhandlingschef Lene Esbensen }\end{array}$ \\
\hline SHK & $\begin{array}{l}\text { Formand Grete Christensen } \\
\text { Forhandlingschef Helle Varming }\end{array}$ \\
\hline FOA & $\begin{array}{l}\text { Formand Dennis Kristensen } \\
\text { Forhandlingschef Jakob Oluf Bang }\end{array}$ \\
\hline SL & Formand Benny Andersen \\
\hline LO & Afdelingschef og advokat Peter Nisbeth \\
\hline
\end{tabular}

* Herudover har vi gennemført fortrolige samtaler med yderligere en række centrale repræsentanter for parterne i det offentlige overenskomstsystem. 
Nana Wesley Hansen, lektor, Københavns Universitet (FAOS) Forskningscenter for Arbejdsmarkeds- og Organisationsstudier e-mail:nha@faos.dk

Mikkel Mailand, lektor, Københavns Universitet (FAOS)

Forskningscenter for Arbejdsmarkeds- og Organisationsstudier e-mail: mm@faos.dk 